\title{
The effects of cervical cerclage practice on perinatal and neonatal outcomes according to the indications
}

\author{
Serdar Kaya' (D) , Fatma Ceren Güner² (D) , Mehmet Şimşek ${ }^{3}$ (D) , Selahattin Kumru³ \\ ${ }^{1}$ Perinatology Division, Clinic of Obstetrics and Gynecology, Bağcular Training and Research Hospital, University of Health Sciences, Istanbul, Turkey \\ ${ }^{2}$ Clinic of Obstetrics and Gynecology, Bilecik State Hospital, Bilecik, Turkey \\ ${ }^{3}$ Perinatology Division, Department of Obstetrics and Gynecology, Faculty of Medicine, Akdeniz University, Antalya, Turkey
}

\begin{abstract}
Objective: The aim was to investigate the perinatal and neonatal outcomes in the cases which underwent cervical cerclage, and to compare the elective and emergency cerclage cases.

Methods: The cases that underwent cervical cerclage in the Hospital of the Faculty of Medicine at Akdeniz University between January 2014 and December 2019 were assessed retrospectively, and separated into 3 categories as the prophylactic, elective and emergency groups. The demographic characteristics and perinatal and neonatal outcomes were recorded and they were compared between the groups.

Results: A total of 92 cases with singleton pregnancy between 12 and 24 weeks of gestation were included in the study. The prophylactic cerclage group consisted of 48 cases, the elective cerclage group consisted of 21 cases and the emergency cerclage group consisted of 23 cases. The rate of the cases delivered at term ( $\geq 37$ weeks of gestation) was found significantly lower in the emergency cerclage group than the rates of the cases in the prophylactic and elective cerclage groups $(26.1 \%, 70.8 \%$ and $66.7 \%$; respectively). While there was no significant difference between the prophylactic and elective cerclage groups in terms of premature preterm labor ( $<32$ weeks of gestation), the rate of premature preterm labor was significantly higher in the emergency cerclage group than two other groups $(10.4 \%, 9.5 \%$ and $43.5 \%$, respectively; $\mathrm{p}=0.005)$. The mean delivery week of the emergency cerclage cases was significantly higher than the prophylactic and elective cerclage groups $(31.7,36.7$ and 36.5 weeks, respectively; $\mathrm{p}<0.001)$. The mean duration between the cerclage procedure and the delivery week was the highest in the prophylactic cerclage cases and the lowest in the emergency cerclage cases (22.8 and 9.7 weeks, respectively; $\mathrm{p}<0.001)$. The mortality rate of the newborns was higher in the emergency cerclage cases than the other groups, which was statistically significant $(\mathrm{p}=0.002)$.

Conclusion: We concluded that the perinatal and neonatal outcomes of the emergency cerclage procedure carried out in the advanced stage of cervical changes in the cases with cervical insufficiency is less successful than the prophylactic and elective cerclage procedures. The early detection of cervical insufficiency by the previous history, the physical examination and the measurement of transvaginal cervical length and responding at the early weeks of gestation may improve the perinatal and neonatal outcomes.
\end{abstract}

Keywords: Cervical cerclage, cerclage indications, perinatal outcomes, neonatal outcomes.

\section{Özet: Endikasyonlarına göre servikal serklaj uygulamasının perinatal ve neonatal sonuçlar üzerine etkisi}

Amaç: Servikal serklaj uygulanan olgularda gebelik ve neonatal sonuçların incelenerek profilaktik, elektif ve acil serklaj olgularının karşılaştırılması amaçlandı.

Yöntem: Ocak 2014 ile Aralık 2019 tarihleri arasında Akdeniz Üniversitesi Tip Fakültesi Hastanesinde uygulanan servikal serklaj olguları retrospektif olarak incelenerek serklaj endikasyonlarına göre profilaktik, elektif ve acil olmak üzere 3 gruba ayrıldı. Olguların demografik özellikleri, gebelik ve neonatal sonuçları kaydedildi ve gruplar arasında karşılaştırma yapıldı.

Bulgular: Çalışmaya 12 ile 24. gebelik haftaları arasında tekil gebeliği olan toplam 92 olgu dahil edildi. Profilaktik serklaj grubu 48 olgu, elektif serklaj grubu $21 \mathrm{olgu}$, acil serklaj grubu ise $23 \mathrm{olgu}-$ dan oluşmaktaydı. Miadında doğum ( $\geq 37$. gebelik haftası) yapan olguların oranı acil serklaj grubunda profilaktik ve elektif serklaj gruplarına göre anlamlı olarak düşük saptandı (sırasıyla \%26.1, $\% 70.8$ ve \%66.7). Erken preterm doğum (<32. gebelik haftası) oranları açısından profilaktik ve elektif serklaj olguları arasında anlamlı fark izlenmezken, acil serklaj olgularında diğer iki gruba göre erken preterm doğum oranı anlamlı olarak yüksek saptandı (s1rasıla \% 10.4 , \%9.5 ve \% 43.5; $\mathrm{p}=0.005)$. Acil serklaj olgularının ortalama doğum haftası profilaktik ve elektif serklaj gruplarına göre anlamlı olarak daha düşüktü (sırasıyla $31.7,36.7$ ve 36.5 hafta; $\mathrm{p}<0.001)$. Serklaj - doğum haftası arasındaki ortalama süre profilaktik serklaj olgularında en yüksek, acil serklaj olgularında en düşüktü (sırasıyla 22.8 ve 9.7 hafta; $\mathrm{p}<0.001$ ). Yenidoğan ölüm oranı acil serklaj olgularında diğer gruplara göre istatistiksel olarak anlamlı şekilde yüksekti ( $\mathrm{p}=0.002)$.

Sonuç: Servikal yetmezliği olan olgularda servikal değişikliklerin ilerlemiş evresinde uygulanan acil serklajın gebelik ve neonatal sonuçlarının profilaktik ve elektif serklaja göre daha başarısız olduğu anlaşılmaktadır. Servikal yetmezliğin öykü, fizik muayene ve transvajinal servikal uzunluk ölçümü ile erken tanınması ve erken gebelik haftalarında müdahalede bulunulması gebelik ve neonatal sonuçları iyileştirebilir.

Anahtar sözcükler: Servikal serklaj, serklaj endikasyonları, perinatal sonuçlar, neonatal sonuçlar.

Correspondence: Serdar Kaya, MD. Perinatology Division, Clinic of Obstetrics and Gynecology, Bağcılar Training and Research Hospital, University of Health Sciences, Istanbul, Turkey. e-mail: kayaserdar75@hotmail.com / Received: May 26, 2020; Accepted: June 23, 2020

Please cite this article as: Kaya S, Güner GC, Şimşek M, Kumru S. The effects of cervical cerclage practice on perinatal and neonatal outcomes according to the indications. Perinatal Journal 2020;28(3):164-169. doi:10.2399/prn.20.0283003 


\section{Introduction}

Cervical insufficiency is a significant reason for the second trimester gestational losses and preterm labors, and it has become an important health problem due to its contribution to the perinatal morbidity and mortality associated with preterm labor. ${ }^{[1,2]}$ It is defined as the insufficiency of cervix to maintain the pregnancy without the symptoms and indications of uterine contraction and labor during the second trimester. ${ }^{[3]}$ Actual cervical insufficiency is seen in less than $1 \%$ of the obstetric population, ${ }^{[4]}$ and it is responsible for $8 \%$ of the recurring gestational losses. ${ }^{[5]}$

Although there is no diagnostic test for the cervical insufficiency, its diagnosis is established by the previous history and physical examination as well as ruling out other potential reasons and by the ultrasonographic measurement of cervical length recently. ${ }^{[3,46]}$ Even though there are other diagnostic tests such as hysterosalpingography, balloon traction, and the insertion of cervical dilatators, the scientific evidences do not support their uses in the diagnosis of cervical insufficiency. ${ }^{[3]}$

The surgical methods such as McDonald and Shirodkar procedures as well as non-surgical methods without proven efficiency (such as bedrest, activity restriction, vaginal ring) are used in the treatment of cervical insufficiency. The transabdominal cervicoisthmic cerclage is another surgical procedure used in cases where transvaginal cerclage cannot be done..$^{[1,3,4]}$

In our study, we aimed to investigate the perinatal and neonatal outcomes of the groups which were established by the cerclage indications by reviewing the records of the cervical cerclage procedures performed in our hospital.

\section{Methods}

The records of 92 cases who had singleton pregnancy and underwent cervical cerclage between January 2014 and December 2019 in the Hospital of the Faculty of Medicine at Akdeniz University were assessed retrospectively in this study. The approval of the ethics committee for the study was obtained from the Ethics Committee of Clinical Researches, Faculty of Medicine, Akdeniz University with the decision no. 70904504/417. The cervical cerclage cases were between 12 and 24 weeks of gestation and McDonald cerclage technique ${ }^{[7]}$ was preferred as it was easier and faster to perform, and cervical cerclage was carried out under general anesthesia by using mersilene tape (Ehicon, West Somerville, MA, USA). While the cases with the history of cervical cerclage in their previous gestations or one or more gestational loss(es) at the second trimester associated with painless cervical dilation without the findings of labor and placental abruption constituted the prophylactic cerclage group with history indication, the cases which were found to have cervical dilation $2 \mathrm{~cm}$ and above but not more than $4 \mathrm{~cm}$ were included in the emergency cerclage group. The cases which were found to have a reduction in the cervical length $(<25 \mathrm{~mm})$ and the history of preterm labor were included in the elective cerclage group. $^{[3]}$ All cases were administered perioperative $1 \mathrm{~g}$ ampicillin every 6 hours for 48 hours prophylactically in addition to the bedrest, and the cases except those in the prophylactic cerclage group were administered $100 \mathrm{mg}$ indomethacin rectally before the procedure and $25 \mathrm{mg}$ indomethacin orally every 6 hours for 24 hours after the procedure as a tocolytic treatment. After the procedure, all cases were recommended daily $200 \mathrm{mg}$ vaginal progesterone. The cases who admitted with membrane rupture, those suspected for chorioamnionitis in the clinic and laboratory, and the cases uterine contraction, vaginal bleeding and multiple pregnancy were excluded from the study. The routine cervical culture was not collected from the cases before the procedure. The demographic characteristics, perinatal results and neonatal results of the patients were recorded.

SPSS version 23 (Statistical Package for the Social Sciences, Chicago, IL, USA) was used for the statistical analysis of the data. The descriptive statistics were presented as mean \pm standard deviation, median (minimum-maximum) and number (percentage). The normal distributions of the continuous variables were tested by Kolmogorov-Smirnov test. The numerical variables not conforming with the normal distribution were compared by Dunnett's multiple comparison test after KruskalWallis test between the groups. The categorical variables between the groups were compared by chi square test and Bonferroni correction. The value of 0.05 was considered as the statistical significance level.

\section{Results}

Of 92 cases included in the study, 48 (52.2\%) constituted the prophylactic cerclage group, 21 (22.8\%) con- 
Table 1. The demographic characteristics of the cases.

\begin{tabular}{|c|c|c|c|c|}
\hline & $\begin{array}{l}\text { Prophylactic cerclage } \\
\qquad(\mathrm{n}=48)\end{array}$ & $\begin{array}{l}\text { Elective cerclage } \\
\qquad(\mathrm{n}=\mathbf{2 1})\end{array}$ & $\begin{array}{l}\text { Emergency cerclage } \\
\qquad(n=23)\end{array}$ & p-value \\
\hline Age (year) & $30.9 \pm 4.8$ & $29.7 \pm 4.3$ & $30.3 \pm 5.0$ & 0.610 \\
\hline Gravida (n) & $3(2-8)$ & $3(1-7)$ & $2(1-5)$ & 0.06 \\
\hline Parity (n) & $1(0-3)^{\mathrm{a}}$ & $1(0-3)^{a, b}$ & $0(0-2)^{b}$ & 0.016 \\
\hline Abortion (n) & $1(0-5)$ & $1(0-2)$ & $1(0-4)$ & 0.223 \\
\hline Hospitalization (day) & $2.8 \pm 1.3^{a}$ & $4.0 \pm 3.9 a, b$ & $7.0 \pm 5.6 \mathrm{~b}$ & $<0.001$ \\
\hline The week of cerclage (week) & $13.8 \pm 1.5^{a}$ & $19.6 \pm 2.1 b$ & $21.5 \pm 2.1 c$ & $<0.001$ \\
\hline
\end{tabular}

The data were presented as mean \pm SD and median (minimum-maximum). a,b,cThe groups with different letters are different than each other in a statistically significant way.

stituted the elective cerclage group, and $23(25 \%)$ constituted the emergency cerclage group. The mean maternal age of the cases was $30.5 \pm 4.7$ and the mean week of gestation was $17 \pm 3$.9. While there was no significant difference between the groups in terms of maternal age, gravida and abortion numbers $(\mathrm{p}=0.610$, $\mathrm{p}=0.06$ and $\mathrm{p}=0.223$; respectively), the parity number was significantly lower in the emergency cerclage group than the prophylactic cerclage group $(\mathrm{p}=0.016)$. The median cervical dilation was $3 \mathrm{~cm}$ in the emergency cerclage group $(2-4 \mathrm{~cm})$. A significant difference was found in terms of the mean week of gestation at which the cerclage procedure was performed $(\mathrm{p}<0.001)$. While there was no statistically significant difference between the prophylactic and elective cerclage cases in terms of hospitalization duration, it was significantly higher in the emergency cerclage group compared to the prophylactic cerclage group $(\mathrm{p}<0.001)$. The demographic characteristics of the cases are shown in Table $\mathbf{1}$.

While $70.8 \%$ of the cases in the prophylactic cerclage group delivered at term (?37 week of gestation), this rate was $66.7 \%$ in the elective cerclage group and
$26.1 \%$ in the emergency cerclage group. The rate of the cases who delivered at term was significantly lower in the emergency cerclage group than the other two groups $(\mathrm{p}=0.005)$. There was no statistically significant difference between the groups in terms of the rates of pregnancy loss $(p>0.05)$. No significant difference was found between the prophylactic cerclage cases and the elective cerclage cases when the groups were compared in terms of the rates of premature preterm labor $(<32$ weeks of gestation), but the rates of premature preterm labor were significantly higher in the emergency cerclage cases than the other two groups $(\mathrm{p}=0.005)$ (Table 2).

While there was no significant difference between the prophylactic cerclage and the elective cerclage groups in terms of mean delivery week and birth weight, the mean delivery week of the cases in the emergency cerclage group was significantly lower than the rates of the cases in the other groups $(\mathrm{p}<0.001)$. No significant difference was found between the groups in terms of APGAR scores $(\mathrm{p}=0.320)$. A significant difference was found between the groups in terms of the mean duration between the week of gestation at which the cerclage procedure was performed and the delivery

Table 2. The perinatal outcomes of the cases by the groups.

\begin{tabular}{lcccc} 
& $\begin{array}{c}\text { Prophylactic cerclage } \\
(\mathbf{n}=\mathbf{4 8})\end{array}$ & $\begin{array}{c}\text { Elective cerclage } \\
(\mathbf{n}=\mathbf{2 1})\end{array}$ & $\begin{array}{c}\text { Emergency cerclage } \\
(\mathbf{n = 2 3})\end{array}$ & $\begin{array}{c}\text { Total } \\
(\mathbf{n}=\mathbf{9 2})\end{array}$ \\
\hline 37 . weeks of gestation* & $34(70.8 \%)^{\mathrm{a}}$ & $14(66.7 \%)^{\mathrm{a}}$ & $6(26.1 \%)^{\mathrm{b}}$ & $54(58.7 \%)$ \\
\hline $32-36+6$ weeks of gestation & $6(12.5 \%)$ & $2(9.5 \%)$ & $3(13 \%)$ & $11(12 \%)$ \\
\hline$<32$ weeks of gestation* & $5(10.4 \%)^{\mathrm{a}}$ & $2(9.5 \%)^{\mathrm{a}}$ & $10(43.5 \%)^{\mathrm{b}}$ & $17(18.5 \%)$ \\
\hline Pregnancy loss & $3(6.3 \%)$ & $3(14.3 \%)$ & $4(10.9 \%)$ & $10(10.9 \%)$ \\
\hline
\end{tabular}

The data were presented as number (percentage). a,bThe groups with different letters are different than each other in a statistically significant way. ${ }^{*} \mathrm{p}<0.05$ 
Table 3. The perinatal outcomes of the cases resulted in live birth.

\begin{tabular}{|c|c|c|c|c|}
\hline & $\begin{array}{l}\text { Prophylactic cerclage } \\
\qquad(\mathrm{n}=45)\end{array}$ & $\begin{array}{l}\text { Elective cerclage } \\
\qquad(\mathrm{n}=18)\end{array}$ & $\begin{array}{l}\text { Emergency cerclage } \\
\qquad(n=19)\end{array}$ & p-value \\
\hline Week of gestation (week) & $36.7 \pm 4.0^{a}$ & $36.5 \pm 1.8^{a}$ & $31.7 \pm 5.9 \mathrm{~b}$ & $<0.001$ \\
\hline Birth weight (g) & $2962.4 \pm 817.2^{a}$ & $2904.4 \pm 437.9^{a}$ & $1922.6 \pm 1129.6^{b}$ & $<0.001$ \\
\hline Cerclage-labor interval (week) & $22.8 \pm 3.9^{a}$ & $16.6 \pm 3.2^{b}$ & $9.7 \pm 5.8 \mathrm{c}$ & $<0.001$ \\
\hline 1-minute APGAR score & $9(4-9)$ & $9(7-9)$ & $8(3-9)$ & 0.320 \\
\hline 5-minute APGAR score & $10(6-10)$ & $10(8-10)$ & $9(6-10)$ & 0.320 \\
\hline Neonatal death & $2(4.4 \%)^{a}$ & $0^{a}$ & $6(31.6 \%)^{b}$ & 0.002 \\
\hline
\end{tabular}

The data were presented as mean \pm SD, median (minimum-maximum) and number (\%). $a, b, c$ The groups with different letters are different than each other in a statistically significant way.

week $(\mathrm{p}<0.001)$. The mean duration between cerclage procedure and delivery week was the highest in the prophylactic cerclage cases and the lowest in the emergency cerclage cases. When the cases born alive were evaluated, the loss was observed during the neonatal period in $6(31.6 \%)$ cases in the emergency cerclage group, and neonatal mortality rate was higher in the emergency cerclage group than the other groups in a statistically significant way $(\mathrm{p}=0.002)$ (Table 3$)$.

\section{Discussion}

Many studies are conducted to prevent preterm labor which is the most important reason of the neonatal morbidity and mortality. Cervical cerclage procedure is one of the treatment methods used to prevent cervical insufficiency and preterm labor associated with it. ${ }^{[1,2]}$ In 1955 , Shirodkar ${ }^{[8]}$ and McDonald ${ }^{[7]}$ right after him suggested the cervical cerclage procedure as a surgical treatment method in the repeating second trimester losses. The cervical cerclage procedure has provided a significant contribution for the prevention of preterm labor and the reduction of perinatal mortality and morbidity rates in the appropriate population with its use for more than 60 years. ${ }^{[1,9]}$ The incidence of the cervical cerclage procedure in the live births has been varying between $0.3 \%$ and $0.4 \%$ in the recent decades. ${ }^{[10]}$

Although there are differences in the definition of cervical insufficiency, 3 different clinical conditions are used as the cervical cerclage indication. The first of them is the cerclage indication due to obstetric history associated with the repeating second trimester pregnancy losses with painless cervical dilation but not associated with contraction and labor (prophylactic), and the second of them is the cerclage due to physical examination related with the detection of cervical dilation during physical examination (emergency). ${ }^{[1,1]}$ It is thought that the short cervix length at the second trimester may be a precursor of the cervical insufficiency and that it may be a preparatory factor for preterm labor and delivery. ${ }^{[12]}$ Therefore, performing cerclage when cervical length is shortened $(<25 \mathrm{~mm})$ is the (elective) cerclage procedure with ultrasound indication. ${ }^{[1,11]}$ We separated the cases that we applied cerclage with similar indications in our clinic into three groups and reviewed them retrospectively.

Stupin et al. conducted their study with the cases who had cervical dilation between 17 and 26 weeks of gestation, and they found live birth rates significantly higher in the emergency cervical cerclage group compared to the group which underwent conservative treatment (bedrest, tocolysis, antibiotherapy) ( $72 \%$ vs. $25 \%$ ). They also found the diagnosis-labor interval and birth weight significantly high in the cerclage group. ${ }^{[13]}$ Similarly, Ciavattini et al. found significantly higher mean delivery week, cerclage-labor interval and term labor rates in the emergency cerclage cases compared to the conservative approach. ${ }^{[14]}$ Zhu et al. reviewed 158 emergency cerclage cases, and they found the rate of live birth $82 \%$, the rate of delivery at term $10 \%$, the rate of premature preterm labor ( $<32$ weeks) $29 \%$, the cerclagelabor interval 52 days, the mean delivery week 30 weeks and the mean birth weight $1934 \mathrm{~g}$, and they reported that the emergency cerclage is effective to extend the pregnancy period and to improve neonatal outcomes. ${ }^{[15]}$ In our emergency cerclage cases, we similarly found that the rate of live birth was $82 \%$, the mean delivery week was 31.7 weeks and the mean birth weight was $1922 \mathrm{~g}$ 
while the rate of delivery at term was $26 \%$, the rate of preterm labor before 32 weeks was $43 \%$ and the abortion rate was $17 \%$. When we reviewed the results of our cases, we found that the data of the emergency cerclage group were consistent with the literature. In the light of the literature and the data of our study, we can conclude that the emergency cervical cerclage procedure to be performed after selecting appropriate patients among the cases, who were found to have cervical dilation in the physical examination, may have positive contributions on the perinatal outcomes.

Karaca et al. evaluated 54 cerclage cases by their indications in their study and reported longer cerclagelabor interval in the prophylactic cerclage group compared to the elective cerclage group and the emergency cerclage group, and they stated that this interval was significantly short in the emergency cerclage group. While they found similar delivery weeks in the prophylactic cerclage group and the elective cerclage group, the delivery week was significantly low in the emergency cerclage group ${ }^{[16]}$ In the study of Chan et al. comparing cerclage cases, the authors found that the cerclage-labor interval and birth weights were significantly higher in the prophylactic cerclage group and the elective cerclage group than the emergency cerclage group. There was no difference between the prophylactic cerclage group and the elective cerclage group in terms of the delivery week and birth weight, but the authors found that cerclagelabor interval was significantly high in the prophylactic cerclage group ${ }^{[17]}$ Similarly, Karahasanoğlu et al. reported similar delivery weeks in the prophylactic and elective cerclage groups, but they found that the delivery week was lower in the emergency cerclage group, but they reported that the difference was not statistically significant. While they reported the rate of delivery at term $75 \%$ in the prophylactic cerclage group, $70 \%$ in the elective cerclage group and $37 \%$ in the emergency cerclage group, they found the abortion rates significantly higher in the emergency cerclage group than the prophylactic and elective cerclage groups. ${ }^{[18]}$ When we reviewed our cases in the groups, we found that the rates of delivery at term were similar in the prophylactic and elective cerclage groups (70\% vs. $66 \%$ ), it was significantly lower in the emergency cerclage group (26\%). The rates of premature preterm labor ( $<32$ weeks) were significantly lower in the prophylactic and elective cerclage groups than the emergency cerclage group.
Although the live birth rates were the highest in the prophylactic cerclage group, the difference between the groups was not statistically significant. While the cerclage-labor interval was the highest in the prophylactic cerclage group, it was the lowest in the emergency cerclage group and there was significant difference between all groups. These results were consistent with the literature, and we observed that the perinatal outcomes of the prophylactic and elective cerclage groups were better than the perinatal outcomes of the emergency cerclage group in general. We considered that the early response without requiring emergency cerclage as much as possible in the patients with cervical insufficiency in particular would provide a positive contribution to the perinatal outcomes. The retrospective design of our study and the low number of patients in the groups should be considered as the limitations.

Berghella et al. showed in their meta-analysis that the cervical cerclage decreased preterm labor rates by $30 \%$ in the singleton pregnancies with previous history of preterm labor which were found to have short cervix in the transvaginal ultrasonography. ${ }^{[19]}$ Although the benefits of the cerclage with ultrasound indication cannot be shown clearly in the patients without previous history of preterm labor, Berghella et al. reported in their meta-analysis that the cervical cerclage is beneficial to reduce the preterm labor risk in the presence of cervical length below $10 \mathrm{~mm}$ in the patients who were found to have short cervix in the ultrasonographic examination but did not have previous history of preterm labor. ${ }^{[20]}$

\section{Conclusion}

Better investigation of the history, careful physical examination and the use of transvaginal ultrasonography for the measurement of cervical length and performing necessary response in the earlier weeks of gestation by detecting cervical insufficiency early in the risky pregnancies may improve the perinatal outcomes associated with the cervical insufficiency. We consider that performing routine cervical length measurement during second-trimester fetal anomaly screening even in the pregnant women without a history may be effective in the reduction of preterm labor rates.

Conflicts of Interest: No conflicts declared. 


\section{References}

1. Harger JH. Cerclage and cervical insufficiency: an evidencebased analysis. Obstet Gynecol 2002;100:1313-27. [PubMed] [CrossRef]

2. Hamilton BE, Martin JA, Osterman MJK, Curtin SC, Matthews TJ. Births: final data for 2014. Natl Vital Stat Rep 2015;64:1-64. [PubMed]

3. American College of Obstetricians and Gynecologists. ACOG Practice Bulletin No.142: cerclage for the management of cervical insufficiency. Obstet Gynecol 2014;123:372-9. [PubMed] [CrossRef]

4. Brown R, Gagnon R, Delisle MF. No. 373-Cervical insufficiency and cervical cerclage. J Obstet Gynaecol Can 2019;41: 233-47. [PubMed] [CrossRef]

5. Drakeley AJ, Roberts D, Alfirevic Z. Cervical stitch (cerclage) for preventing pregnancy loss in women. Cochrane Database Syst Rev 2003;(1):CD003253. [PubMed] [CrossRef]

6. To MS, Skentou C, Liao AW, Cacho A, Nicolaides KH. Cervical length and funneling at 23 weeks of gestation in the prediction of spontaneous early preterm delivery. Ultrasound Obstet Gynecol 2001;18:200-3. [PubMed] [CrossRef]

7. McDonald IA. Suture of the cervix for inevitable miscarriage. J Obstet Gynaecol Br Emp 1957;64:346-50. [PubMed] [CrossRef]

8. Shirodkar VN. A new method of operative treatment for habitual abortion in the second trimester of pregnancy. The Antiseptic 1955;52:299-300.

9. Berghella V, Keeler SM, To MS, Althuisius SM, Rust OA. Effectiveness of cerclage according to severity of cervical length shortening: a meta-analysis. Ultrasound Obstet Gynecol 2010; 35:468-73. [PubMed] [CrossRef]

10. Friedman AM, Ananth CV, Siddiq Z, D'Alton ME, Wright JD. Trends and predictors of cerclage use in the United States from 2005 to 2012. Obstet Gynecol 2015;126:243-9. [PubMed] [CrossRef]

11. Boelig RC, Berghella V. Current options for mechanical prevention of preterm birth. Semin Perinatol 2017;41:452-60. [PubMed] [CrossRef]

12. Iams JD, Goldenberg RL, Meis PJ, Mercer BM, Moawad A, Das A, et al. The length of the cervix and the risk of spontaneous premature delivery. National Institute of Child Health and Human Development Maternal Fetal Medicine Unit Network. N Engl J Med 1996;334:567-72. [PubMed] [CrossRef]

13. Stupin JH, David M, Siedentopf JP, Dudenhausen JW. Emergency cerclage versus bed rest for amniotic sac prolapse before 27 gestational weeks. A retrospective, comparative study of 161 women. Eur J Obstet Gynecol Reprod Biol 2008;139: 32-7. [PubMed] [CrossRef]

14. Ciavattini A, Delli Carpini G, Boscarato V, Febi T, Di Giuseppe J, Landi B. Effectiveness of emergency cerclage in cervical insufficiency. J Matern Fetal Neonatal Med 2016;29: 2088-92. [PubMed] [CrossRef]

15. Zhu LQ, Chen H, Chen LB, Liu YL, Tian JP, Wang YH, et al. Effects of emergency cervical cerclage on pregnancy outcome: a retrospective study of 158 cases. Med Sci Monit 2015; 21:1395-401. [PubMed] [CrossRef]

16. Karaca İ, Yapça ÖE, Delibaş İB, İngeç M. Cervical incompetence: Comparison the prophylactic and therapeutic procedures. Perinatal Journal 2013;21:7-11. [CrossRef]

17. Chan LLK, Leung TW, Lo TK, Lau WL, Leung WC. Indications for and pregnancy outcomes of cervical cerclage: 11-year comparison of patients undergoing history-indicated, ultrasound-indicated, or rescue cerclage. Hong Kong Med J 2015;21:310-7. [PubMed] [CrossRef]

18. Karahasanoğlu A, Çilingir IU, Deregözü A, Akın H, Hocagil Z, Yücel O. Cervical cerclage complications: eight years of experience. Perinatal Journal 2014;22:99-104. [CrossRef]

19. Berghella V, Rafael TJ, Szychowski JM, Rust OA, Owen J. Cerclage for short cervix on ultrasonography in women with singleton gestations and previous preterm birth: a meta-analysis. Obstet Gynecol 2011;117:663-71. [PubMed] [CrossRef]

20. Berghella V, Ciardulli A, Rust OA, To M, Otsuki K, Althuisius $\mathrm{S}$, et al. Cerclage for sonographic short cervix in singleton gestations without prior spontaneous preterm birth: systematic review and meta-analysis of randomized controlled trials using individual patient-level data. Ultrasound Obstet Gynecol 2017; 50:569-77. [PubMed] [CrossRef] 